\title{
5 GBIT/S ( 2 X 2.5 GBIT/S) REPEATERLESS WDM TRANSMISSION OVER 250 KM OF DISPERSION-SHIFTED FIBER USING DIRECT MODULATION
}

\author{
J.Salomão Pereira, R.Y. Nakamura, S. Celaschi, \\ CPqD -TELEBRÁS, 13088-061 - Campinas - SP e
}

A.C. Pereira Netto

Divisão de Sistemas Ópticos - Embratel - 20179-900 Rio de Janeiro - RJ

\begin{abstract}
RESUMO: Este trabalho apresenta os resultados obtidos em um experimento de transmissão óptica, a $2 \times 2.5 \mathrm{Gbit} / \mathrm{s}$, em dois canais multiplexados em comprimento de onda (WDM) separados por 2 (dois) $\mathrm{nm}$, através de $250 \mathrm{~km}$ de fibra com dispersão deslocada (DSF), utilizando modulação direta nos transmissores. A sensibilidade na recepção após $250 \mathrm{~km}$ é comparada com aquela obtida acoplando-se o receptor diretamente ao transmissor. Não foi observada degradação apreciável na sensibilidade do receptor, demonstrando a aplicabilidade do resultado em um sistema de transmissão óptica.
\end{abstract}

ABSTRACT: We report on a repeaterless transmission of $2 \times 2.5 \mathrm{Gbit} / \mathrm{s}, 2 \mathrm{~nm}$ spaced WDM channels over $250 \mathrm{~km}$ of dispersion-shifted fiber (DSF) using, as light sources, directly modulated DFB lasers. Back-to-back sensitivity was compared with $125 \mathrm{~km}$ and $250 \mathrm{~km}$ of transmission through DSF, for different transmitter power levels, and no significant power penalty was observed

Keywords: Optical Communication, Wavelength Division Multiplexing

\section{1 - INTRODUCTION}

Wavelength-division multiplexing (WDM) in long-span repeaterless transmission links is attractive due to its potential applications in submarine festoon systems. Intensive research has been focused on such WDM repeaterless systems using Erbium Doped Fiber Amplifiers (EDFA) as post- and preamplifiers[1]. To maximize the distances between transmitter and receivers, high launched powers are required. Unfortunately, at high fiber-input powers, signal degradation caused by fiber non

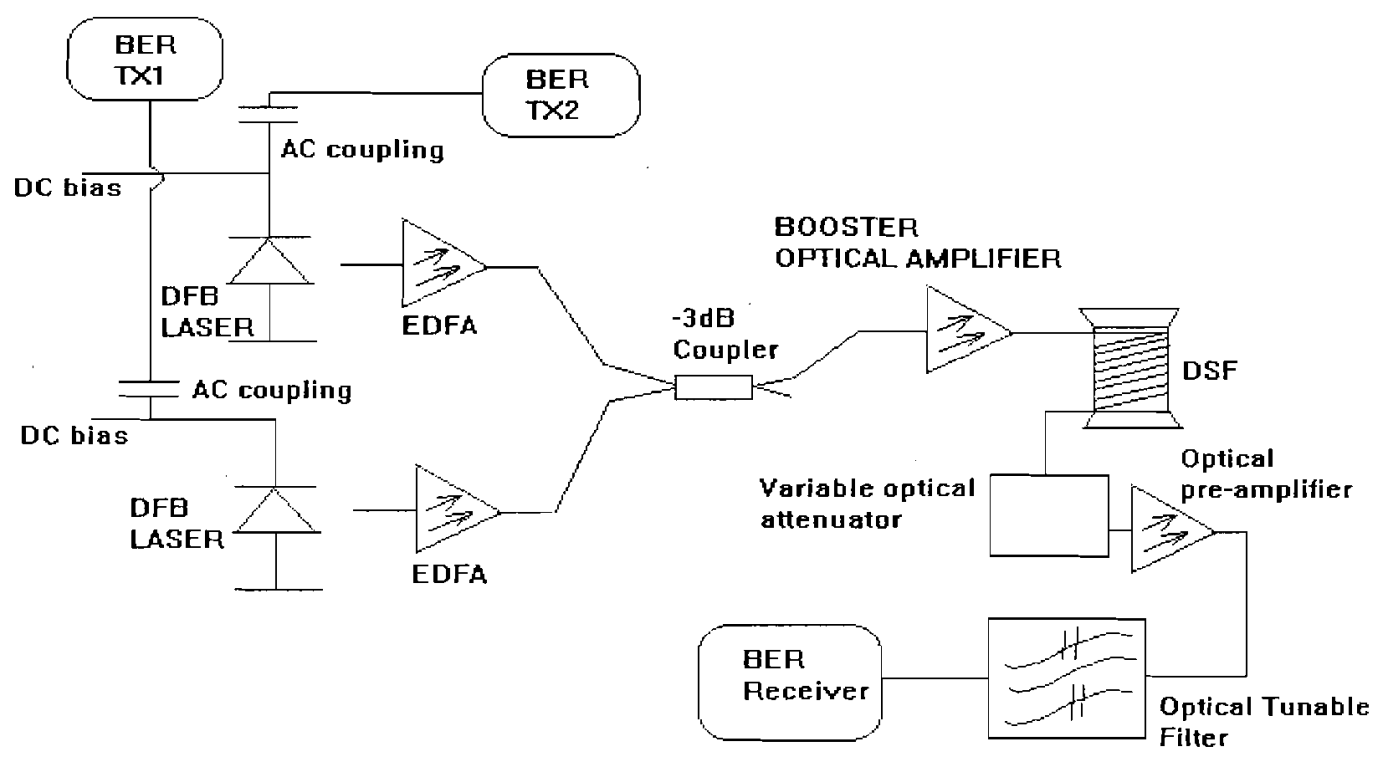

Fig 1 Experimental set-up 
linear effects may limit the repeaterless span[2]. These fiber non linearities are more pronounced when narrow linewidth sources are used in conjunction with near-zero dispersion fibers[3]. Even though, in repeaterless transmission systems external modulation of the optical source has been preferred over direct modulation to reduce the influence of chromatic dispersion. The use of external modulation, in long span repeaterless optical communication system requires dithering of the lasing wavelength, to overcome stimulated Brillouin scattering (SBS). Directly intensity modulated WDM systems are very attractive due to its simplicity and can overcome the dispersion penalty by the use of a DSF. Previously, single optical carrier transmission over $310 \mathrm{~km}$ at $1.8 \mathrm{Gbit} / \mathrm{s}$ using DSFhave been demonstrated using direct modulation of the DFB laser [4]. This paper presents a $2 \mathrm{X}$ $2.5 \mathrm{Gbit} / \mathrm{s}$ direct modulated WDM repeaterless transmission experiment through $250 \mathrm{~km}$ of DSF. The experiment was realized without dispersion management, setting the optical channels only $2 \mathrm{~nm}$ apart. No significant power penalty was observed after $250 \mathrm{~km}$ of DSF using the NRZ-format transmission.

\section{2 - EXPERIMENTAL SET-UP}

Figure 1 shows the experimental set-up. The signal light sources are two DFB lasers fabricated at CPqDTELEBRÁS. The lasers are thermally stabilized and directly modulated, with an extinction ratio of approximately 10 . Two independent $2.5 \mathrm{Gbit} / \mathrm{s}$ pseudorandon NRZ sequences were used. The wavelengths are set to $1542 \mathrm{~nm}$ and $1544 \mathrm{~nm}$ with a chirped linewidth estimated to be $12 \mathrm{GHz}$. In order to reach power levels able to saturate the optical post-amplifier, both channels are amplified by two independent EDFAs. The wavelength multiplexing is obtained by a $3 \mathrm{~dB}$ achromatic coupler. The saturated optical output power of the postamplifier is adjustable up to $+24.3 \mathrm{dBm} .250 \mathrm{~km}$ of DSF ( $\lambda_{0}=1548 \pm 0.5 \mathrm{~nm}$ ) with $0.23 \mathrm{~dB} / \mathrm{km}$ attenuation was used as the transmission medium.

At the receiver, both signals are pre-amplified by a low noise EDFA, and the channel is selected by a $0.7 \mathrm{~nm}, @-3$ $\mathrm{dB}$ bandwidth optical tunable filter. The receiver front end is composed by pin photodiode and a low noise transimpedance amplifier. The sensitivity of optically preamplified receiver is $-38 \mathrm{dBm} @ 10^{-10}$.

\section{3 - EXPERIMENTAL RESULTS AND CONCLUSION DISCUSSION :}

In order to evaluate receiver degradation due to non-linear effects, we measured the BER (bit-error rate) versus sensitivity characteristics for three different transmitter power levels distributed over both channels: $14 \mathrm{dBm}, 19.4$ $\mathrm{dBm}$ and, $24 \mathrm{dBm}$. BER for this two-channel experiment are shown in Fig. 2 for $125 \mathrm{~km}$ of transmission through DSF. The back-to-back difference of $1 \mathrm{~dB}$ observed between channels can be traced to differences in the bias/extinction ratio settings at the LD transmitters. No significant power penalty was observed in these experiments realized without any dispersion management. Furthermore, there is no evidence of BER floor for measured BER values as low as $10^{-11}$ at both channels.

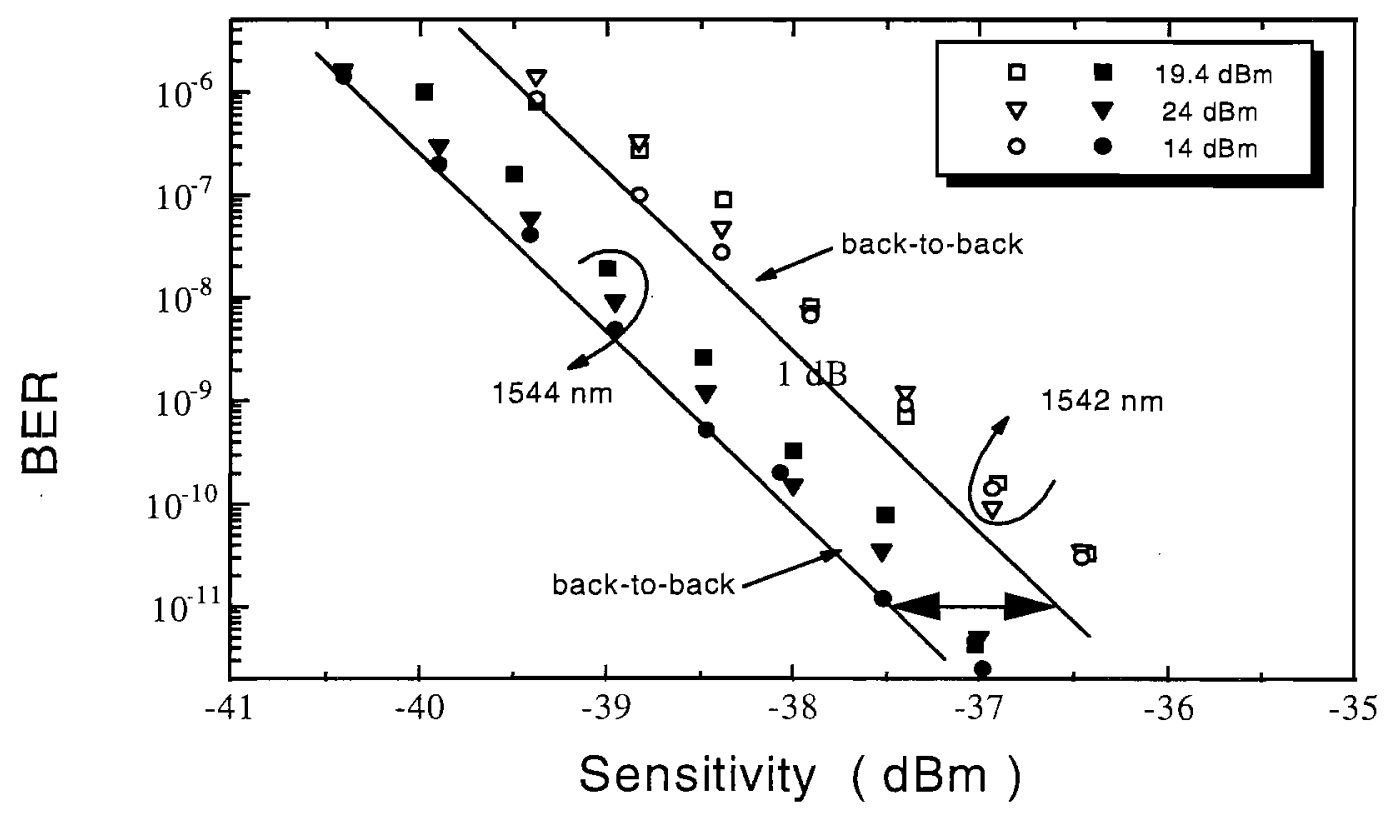

Fig. 2 BER versus receiver sensitivity for both channels at three different transmitter power levels 


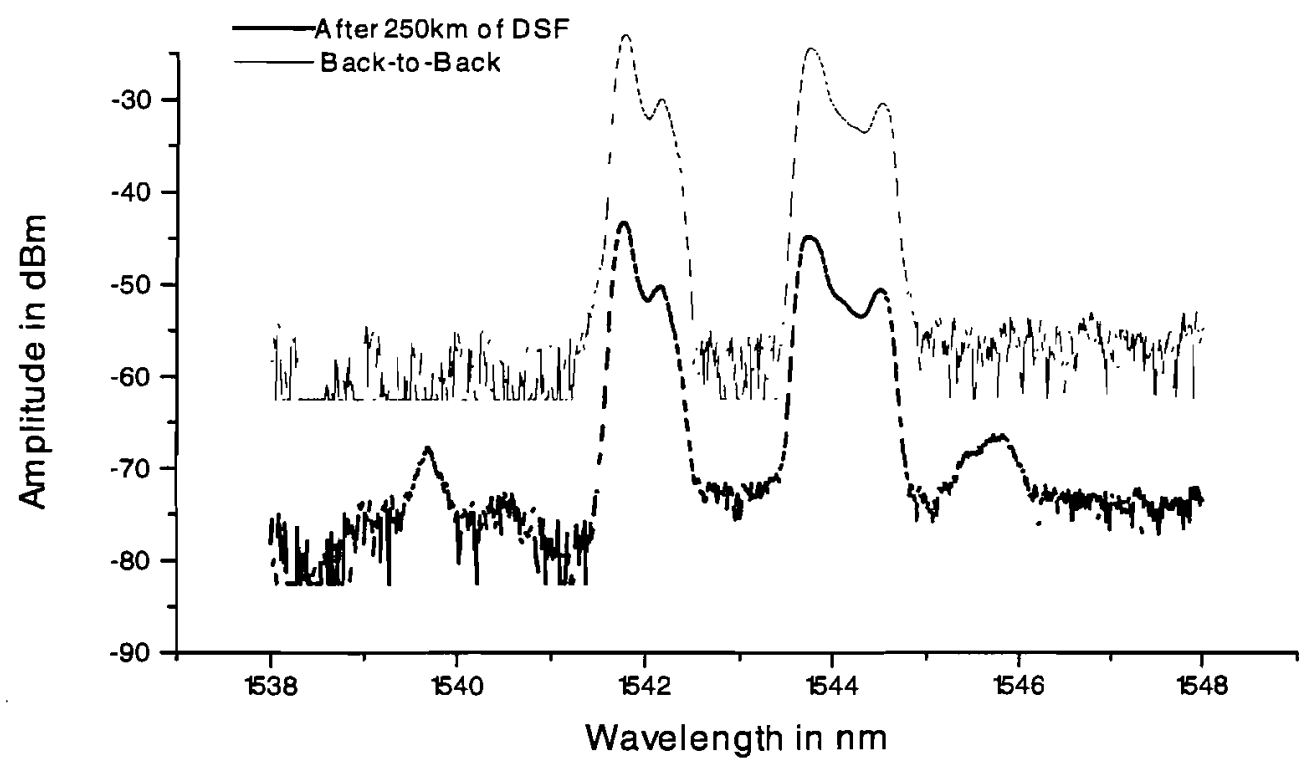

Fig 3 Optical spectrum after $250 \mathrm{~km}$ of propagation through DSF. The output of the booster amplifier is set to $+24 \mathrm{dBm}$

Figure 3 shows the optical spectrum transmitted in both situations : over $250 \mathrm{~km}$ of DSF and back-to-back. The four wave mixing (FWM) lines are evident in the optical spectrum obtained after of $250 \mathrm{~km}$ of DSF. For a two wavelength WDM experiment the receiver power penalty due to FWM is negligible. The optical spectrum which travels $250 \mathrm{~km}$ of DSF shows a low intensity band between the laser peaks. This band can be attributed to cross phase modulation (XPM)[5].

Figure 4 shows the eye diagrams for both channels after $250 \mathrm{~km}$ transmission. These results could be explained based on the decreasing of spectral power density. The broad linewidth of the direct modulated lasers $(12 \mathrm{GHz})$ reduces the spectral power density increasing the non linear threshold for SBS, and reducing the effects of FWM.

For $22 \mathrm{dBm}$ launched power per channel at the transmitter, the power budget deduced from Fig. 2 ranges from $58.5 \mathrm{~dB}\left(10^{-11} \mathrm{BER}\right)$ at $1542 \mathrm{~nm}$ to $59.5 \mathrm{~dB}\left(10^{-11}\right.$ $\mathrm{BER})$ at $1544 \mathrm{~nm}$. The total loss of the $250 \mathrm{~km}$ fiber spool is $57.5 \mathrm{~dB}$, which demonstrates the viability for implementing such WDM links. This reported loss budget achieved without remoted pumped optical amplifiers and/or forward error correction schemes enables simple network upgrade to match traffic growth.

We transmit $2 \times 2.5 \mathrm{~Gb} / \mathrm{s}$ direct modulated lasers, in a WDM configuration, over $250 \mathrm{~km}$ of DSF, with $2 \mathrm{~nm}$ channel spacing. No significant transmitter or receiver sensitivity degradation was observed due to non linear effects as well as dispersion. The spectral linewidth broadening resulting from the transmission of chirped signals can qualitatively explain these results.

\section{CONCLUSION}

We transmit $2 \times 2.5 \mathrm{~Gb} / \mathrm{s}$ direct modulated lasers, in a WDM configuration, over $250 \mathrm{~km}$ of DSF, with $2 \mathrm{~nm}$ channel spacing. No significant transmitter or receiver sensitivity degradation was observed due to non linear effects as well as dispersion. The spectral linewidth broadening resulting from the transmission of chirped signals can qualitatively explain these results.

\section{Acknowledgments .}

The authors would like to thank. M.A. Ongarelli,. R. Heirinch and R. Petry from $C P q D$, and W. Zampa and M.A. Scoco from Pirelli Brazil for the technical support.

The authors also would like to thank Mr. J.B. Rosolém, Mr A.C. Bordeaux Rego, Dr C. Évora, Mr. F.A.S. Pereira, Mr. J.F. C. Cavalcanti and Dr H. Fragnito for the helpful discussions.

\section{REFERENCES :}

[1] S. Sian, S.M. Webb, K.M. Guild and D.R. Terrence, "40 Gbit/s (16 × $2.5 \mathrm{Gbit} / \mathrm{s})$ unrepeatered transmission over $427 \mathrm{~km}$ ", Electron. Lett., 32(1), 50 (1996).

[2]A.R.Chraplyvy, "Limitations on Lightwave Communications Imposed by Optical-Fiber 
Nonlinearities", Journal of Lightwave Technology, vol 8, NO. 10, 1990

[3] A.H. Gnauck, "Recent Progress in high-capacity longhaul WDM systems, OFC'96 Technical Digest paper Tu15.

[4] K. Aida et al., Proc. European Conf. on Optical Commun., ECOC'89, September 1989, Gothenburg, PDA-7.

[5] Kikuchi, N., Sekine, K., Sasaki, S.,'Impact of crossphase modulation on WDM transmission over dispersion-shiffted fiber, OFC'96 Technical Digest, paper Tul 1

Jorge Salomão Pereira received BS and MS degrees in elctrical engineer from UNICAMP. in 1982 and 1993 respectively. In 1982 he joined CPqD TELEBRÁS, Campinas, where he was engaged in research ofoptoelectronic devices and optical communication system. Currentely, he is working on optical wavelength divion multiplexed systems.

Mr J. Salomão is a member of the Brazilian Telecommunication Society.
R.Y. Nakamura received BS in electrical engineer from UNICAMP in 1986. At the same year he joined CPqD TELEBRÁS where he was engaged in digital transmission and optical communication. Currentely he is working on SDH and ATM. Mr Nakamura is a member of the Brazilian Telecommunication Society and Brazilian Telecommunication Comitee of Communication Ministry.

S. Celaschi . PhD in applied physics from Stanford University, USA in 1983. Professor and Research at Institute of Physics and Chemistry of Sao Paulo State University at S. Carlos, SP (1974 -1977), Physics Dept. of Pernambuco University (1977 - 1979) and University. of Viçosa, 1983 - 1984.

Since 1984 engaged in R\&D at TELEBRÁS on optical fibers, devices and optical amplifiers.

A.C. Pereira Netto . Received BS and MS degrees in Telcommunication Engineer both from PUC - RJ in 1971 and 1981 respectively. Dr Pereira Netto received Doctor degree from University Gama Filho, RJ, in 1984. Currentely he is the mananger of Optical System Division at EMBRATEL.
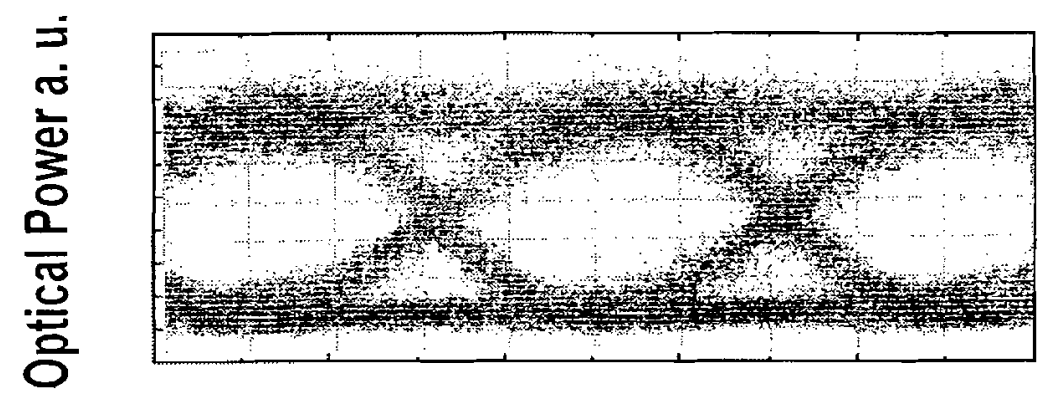

(a)

100ps/div

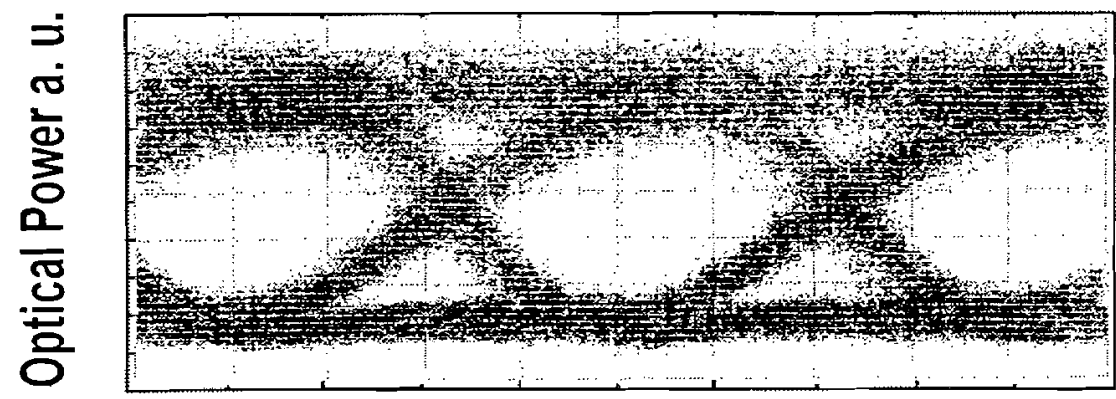

(b)

\section{0ps/div}

Fig 4 Eye diagram of both channels after $250 \mathrm{~km}$ transmitted through DSF. (a) $1542 \mathrm{~nm}$, (b) $1544 \mathrm{~nm}$ 